\title{
Correction to: Sucrose affects the developmental transition of rhizomes in Oryza longistaminata
}

\author{
Kanako Bessho-Uehara ${ }^{1}$ Jovano Erris Nugroho ${ }^{1} \cdot$ Hirono Kondo $^{1} \cdot$ Rosalyn B. Angeles-Shim $^{1,2} \cdot$ Motoyuki Ashikari $^{1}$
}

Published online: 29 April 2019

(c) The Author(s) 2019

\section{Correction to: Journal of Plant Research (2018) 131:693-707 https://doi.org/10.1007/s10265-018-1033-x}

The article Sucrose affects the developmental transition of rhizomes in Oryza longistaminata, written by Kanako Bessho-Uehara, Jovano Erris Nugroho, Hirono Kondo, Rosalyn B. Angeles-Shim, Motoyuki Ashikari, was originally published electronically on the publisher's internet portal (currently SpringerLink) on 8 May 2018 without open access.

With the author(s)' decision to opt for Open Choice the copyright of the article changed on 5 May 2019 to () The Author(s) 2019 and the article is forthwith distributed under the terms of the Creative Commons Attribution 4.0 International License (http://creativecommons.org/licenses/ by/4.0/), which permits use, duplication, adaptation, distribution and reproduction in any medium or format, as long as you give appropriate credit to the original author(s) and the source, provide a link to the Creative Commons license and indicate if changes were made.

Open Access This article is distributed under the terms of the Creative Commons Attribution 4.0 International License (http://creativecommons.org/licenses/by/4.0/), which permits unrestricted use, distribution, and reproduction in any medium, provided you give appropriate credit to the original author(s) and the source, provide a link to the Creative Commons license, and indicate if changes were made.

The original article was corrected.

Open Access This article is distributed under the terms of the Creative Commons Attribution 4.0 International License (http://creativeco mmons.org/licenses/by/4.0/), which permits unrestricted use, distribution, and reproduction in any medium, provided you give appropriate credit to the original author(s) and the source, provide a link to the Creative Commons license, and indicate if changes were made.

The original article can be found online at https://doi.org/10.1007/ s10265-018-1033-x.

Motoyuki Ashikari

ashi@agr.nagoya-u.ac.jp

1 Bioscience and Biotechnology Center, Nagoya University, Furo-cho, Chikusa, Nagoya, Aichi 464-8601, Japan

2 Department of Plant and Soil Science, Texas Tech University, Lubbock, TX 79409, USA 